\title{
The financial impact of Spanish pension reform: A quick estimate ${ }^{*}$
}

\author{
Angel de la Fuente \\ Instituto de Análisis Económico (CSIC) and Barcelona GSE \\ and \\ Rafael Doménech \\ BBVA Research and University of Valencia
}

Revised, April 2012

\begin{abstract}
In this paper we present a preliminary estimate of the financial impact of the recent reform of the Spanish pension system. After updating the projections of pension expenditure constructed in de la Fuente and Doménech (2010) for the period 2008-60, we analyze the impact on this variable of raising the retirement age from 65 to 67 years, extending from 15 to 25 years the period over which wages are averaged to calculate the starting pension and increasing from 35 to 37 the number of contribution years required to obtain a "full pension." Conditional on a series of assumptions about the evolution of employment, productivity and demographics, our estimates suggest that these measures will reduce pension expenditure by up to 1.4 percentage points of GDP once the reforms have been fully implemented in 2027, thereby stabilizing pension expenditure at a bit over $9 \%$ of GDP during the transition period and preventing the emergence of a structural deficit in the system before the end of the next decade. On the other hand, the existing uncertainty about the future evolution of the relevant variables suggests that it would be desirable to bring forward in time the introduction of the periodic evaluation of the system (the so-called sustainability factor) so as to have in place a mechanism that can be used to modulate the rhythm and scope of the reform if the system's financial situation requires it before the end of the transitional period.
\end{abstract}

Keywords: pension reform, Spain, retirement age JEL Classification: H55, J11

- We gratefully acknowledge financial support from BBVA Research and from the Spanish Ministry of Science and Innovation through projects ECO2011-28348 and ECO2011-29050. 


\section{Introduction}

This paper presents a preliminary estimate of the impact of the reform of the Spanish public pension system approved by Parliament in late July 2011 (BOE, 2011). Our starting point is the estimate of expenditure in the absence of reforms presented in de la Fuente and Doménech (2010) for the 2008-2060 period, which in turn relies on Eurostat's recent population projections for Spain. After making some adjustments to these projections in light of recent experience, we analyze the impact on expected pension expenditure and on the system's net financial balance of the three main measures included in the reform package: raising the retirement age from 65 to 67 years for workers with less than 38.5 years of social contributions, extending from 15 to 25 years the period over which wages are averaged to calculate the starting pension (the "pension calculation period") and increasing from 35 to 37 the number of years of social contributions that are required to be entitled to a "full pension" (i.e., to $100 \%$ of the so-called regulatory base of the pension).

The rest of the paper is divided into six sections and an appendix. Section 2 describes the recent reform and places it in context. Section 3 outlines the methodology that will be used to project pension expenditure in coming decades. Section 4 presents the baseline scenario - in which the present system remains unchanged - and section 5 quantifies the effects of the reform. Section 6 concludes with a brief summary of the implications of the analysis and some recommendations derived from them. Finally, the appendix collects some technical details on data sources and on the Eurostat population projections we take as a reference.

\section{The Spanish pension reform of 2011}

An active debate on pension reform has been raging in Spain for almost twenty years. Starting in the mid 1990s, academics, private analysts and international organizations have produced numerous warnings about the adverse effects of rapid aging on pension finances and have insisted on the need to curtail the system's generosity in order to guarantee its longterm sustainability. ${ }^{1}$ Until recently, however, the ongoing debate has translated into only minor adjustments of the public pension system as all political parties have been extremely reluctant to even discuss impopular measures that would have been strongly opposed by militant labor unions. Between the mid 1990s and the onset of the current crisis, moreover,

\footnotetext{
1 There is an extensive literature on the sustainability of the Spanish pension system. Among many other studies, see MTSS (1995), Barea et al (1995, 1996 and 1997), Herce et al (1996), Boldrin et al (1999), Jimeno and Licandro (1999), Jimeno (2000), da Rocha and Lores (2005), Díaz Giménez and Díaz Saavedra (2006 and 2008), Conde and Alonso (2006), EPC (2006), Gil et al (2007), Jimeno, Rojas and Puente (2008), MTIN (2008), Doménech and Melguizo (2008) and Moral-Arce et al (2008).
} 
strong migratory inflows and rapid employment growth helped improve the system's finances by reducing dependency ratios and diminished the perceived urgency of the reforms.

In recent years, however, the situation has radically changed. The current economic crisis has brought with it a dramatic deterioration of Spanish public finances and increasing pressure from our EU partners and from financial markets to bring the public deficit (which exceeded $11 \%$ of GDP in 2009) under control. The situation has forced the Spanish Government to adopt drastic fiscal consolidation measures starting in May 2010 and to publicly commit itself to a series of structural reforms that are widely considered necessary to facilitate growth, reduce unemployment and restore budget balance.

The recently approved reform of the pension system has been a key component of this reformist strategy from the start. Given the large and rising weight of pensions in public expenditure, their reform is surely one of the most effective levers in the Government's hands to improve the long-term sustainability of our public finances - and, perhaps even more crucially, to influence market perceptions of long term solvency risks, which can have immediate effects on sovereign risk premia and on credit availability. Awareness of this fact has probably contributed a lot to the Government's resolve to actively pursue a serious reform of the pension system. A crucial factor that helped insure its success has been the weak position in which labor unions found themselves after the widespread failure of the general strike they organized in September 2010 to protest against the Government's fiscal consolidation plans. Fearing a new setback, the two main national trade unions preferred to avoid an all-out confrontation and accepted to enter into negotiations with the Government and the Employer Confederations to reach an agreement on the reform, focusing their efforts on softening some aspects of the original Government proposal, particularly in connection with the raising of the retirement age.

The end result of the process was a tripartite agreement on what must be considered by Spanish standards a rather ambitious reform of the public pension system. The document signed in January 2011 by the Spanish Government and the social partners (ASE, 2011) and passed into law seven months later with minor changes (BOE, 2011) contains three key measures which will be implemented gradually between 2013 and 2027: raising the retirement age from 65 to 67 years, extending the pension calculation period from 15 to 25 years and increasing from 35 to 37 the number of contribution years required to reach $100 \%$ of the regulatory base. ${ }^{2}$ In addition, the new law introduces a so-called sustainability factor, a quinquennial evaluation of the system that, starting in 2032, will trigger whatever parametric adjustments are necessary to ensure its sustainability, but does not specify how such adjustments will be calculated beyond requiring that this be done taking into account the observed increase in life expectancy at 67. Finally, the recent law includes additional measures that affect the minimum retirement age and the incentives to postpone retirement

\footnotetext{
2 The law also modifies the scale that relates the number of contribution years with the percentage of the regulatory base to be collected as a pension. It does not change, however, the minimum requirement of 15 years of contributions (to be entitled to $50 \%$ of the regulatory base).
} 
among other things and envisages exceptions to some of the new pension rules. Perhaps the most important of these exceptions has to do with the possibility of maintaining retirement at the age of 65 for long contribution careers (understood as those of at least 38.5 years) and for workers engaged in especially risky or arduous activities. We estimate that this provision may in practice exempt up to $50 \%$ of the relevant population from the planned increase in the retirement age. ${ }^{3}$

Figure 1: Timetable for the implementation of the main reforms
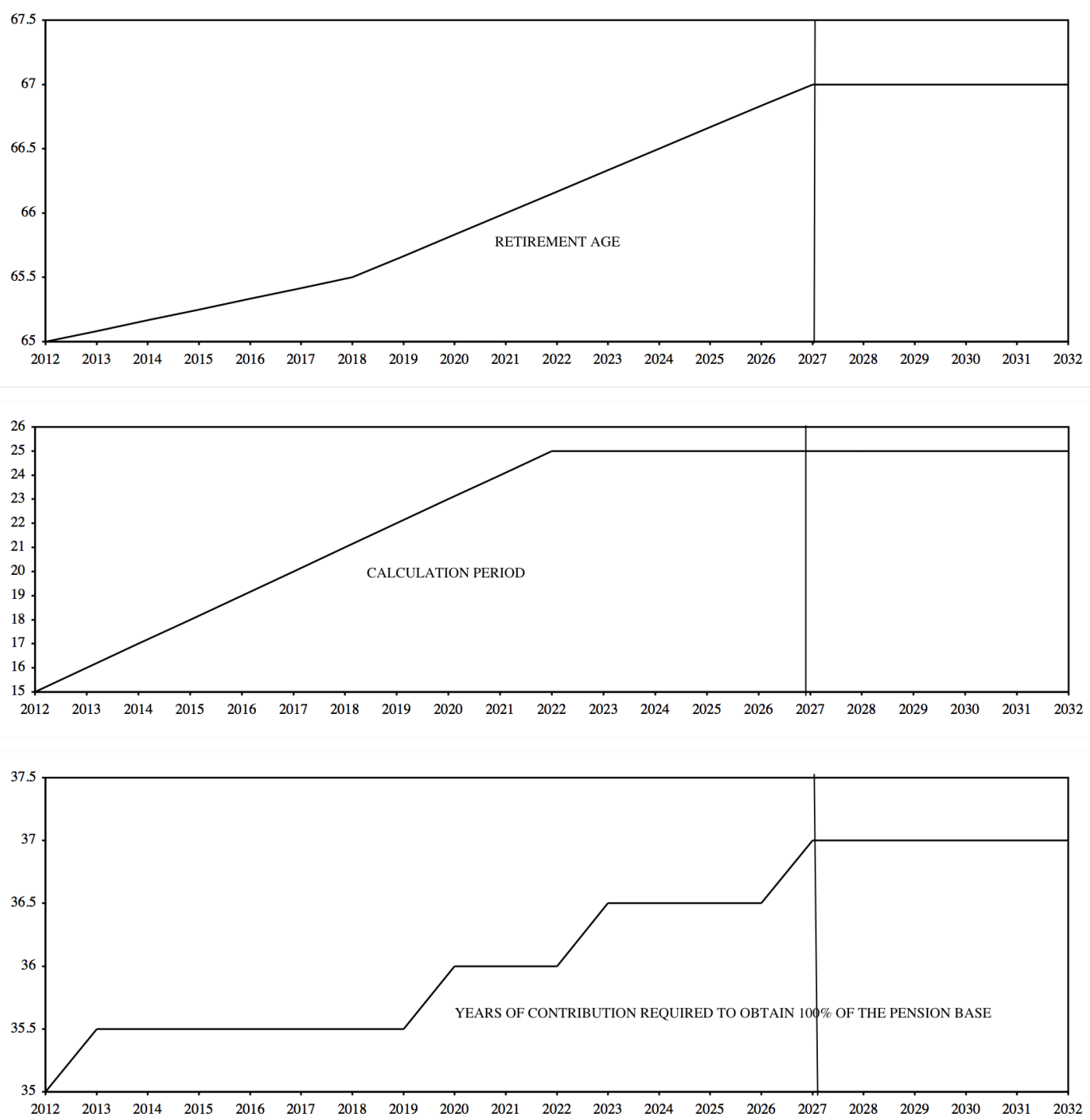

Figure 1 summarises the timetable for the application of the reform. The retirement age will rise gradually, at a rate of one month per year between 2013 and 2018 and two months per year between 2019 and 2027. The calculation period will be increased from 15 to 25 years at a uniform pace between 2013 and 2022. Finally, the contribution period required to be entitled

\footnotetext{
3 According to MITIN (2011b, p. 159) 64.5\% of those entering retirement in 2011 had at least 35 years of contribution. Devesa $(2009$, p. 64$)$ reports that, on average, the affiliates to the General Regime entering retirement in 2008 had paid social contributions during 38.1 years. Bank of Spain (2011, p. 66) also reaches a similar conclusion using data from the Continuous Sample of Working Lives.
} 
to $100 \%$ of the regulatory base will be increased in six-month steps in 2013, 2020, 2023 and 2027, with simultaneous adjustments in the scale relating the number of years of contribution to the amount of the pension, as set forth in a scale included in the law (BOE 2011, art. 4.6).

These reforms are in line with those adopted in recent years by other European countries. ${ }^{4}$ Austria, Belgium, Denmark, France, Germany, Greece, Ireland, Italy and the United Kingdom have increased the official retirement age. Additionally, Denmark, Finland, France, Germany, Italy, Portugal and Sweden have introduced different sustainability corrections in pension calculations based on life expectancy or dependency ratios. The system resulting from the Spanish reform closely resembles the German model, although with a much higher replacement rate (ratio between the first pension and the last salary) and a lower number of years required for early retirement or to be entitled to a "full pension." After the reform, the official retirement age is the same in both countries (67 years), whereas the number of contribution years for a full pension is 38.5 in Spain vs 45 in Germany. Similarly, the number of contribution years (33) required for early retirement (between 61 and 63 years of age) is slightly lower in Spain than in Germany (35 years of contribution for retirement at 63).

\section{A methodology for projecting pension expenditure}

Our projections of spending on contributory pensions with and without the recent reform are constructed using two instruments. The first one is a decomposition of this variable, measured as a percentage of GDP, into a series of factors that reflect, respectively, how pension expenditure is influenced by demographic factors, the evolution of employment and the generosity of the system, as measured by the ratio between the average pension and average output per employed worker. ${ }^{5}$ Modelling the evolution of the first two factors is, in principle, a simple exercise. If we take as a given the population projections elaborated by Spain's National Statistical Institute (INE) or by Eurostat, we only need to make an assumption regarding the evolution of employment in order to project the behavior of the ratio between employed and retired persons, which is about half the story we want to tell.

The other half is related to the evolution of the "generosity" ratio of the public pension system and poses more difficult problems, partly because the time path of this indicator is not independent from that of employment (through the average years of contribution of the stock of pensioners) and partly because its value depends in a complex manner on a series of parameters that summarize the procedure used to calculate each individual's pension on the basis of his contribution record (including, for instance, the number of years over which wages are averaged to calculate the pension's regulatory base). The instrument we will use to tackle this second problem is a highly simplified model of aggregate pension expenditure developed in de la Fuente (2011). The model can be used to calculate the steady-state value

\footnotetext{
4 For a review of the reforms undertaken in other European countries in recent years, see Alonso and Conde (2007), OECD (2009 and 2011) and Bank of Spain (2011).

5 The term "generosity ratio" has been used in this context by different authors and institutions, including the IMF (2010) and Cotlear (2011). An alternative term also found in the literature for the ratio of interest would be the "benefit ratio." In the present paper, "generous" means "large" in relation to average output per worker, without any charity-like or free-lunch connotations.
} 
towards which the generosity ratio of the system can be expected to converge in the long term in the absence of policy changes and under the assumption of constant rates of growth of productivity and employment. The short- and medium-term dynamics of the generosity ratio will be modelled as a process of gradual convergence towards the steady state described by the model.

\subsection{The components of pension expenditure}

To analyze the dynamics of pension expenditure as a fraction of GDP, it is useful to start by writing this ratio as the product of three factors that reflect, respectively, the influence of demography, employment and the benefit level or generosity of the pension system. ${ }^{6}$

Let PEXP be total expenditure on pensions. The ratio of this magnitude to GDP can be written as follows

$$
\text { (1) } \frac{P E X P}{G D P}=\frac{N P E N S}{L} \frac{\frac{P E X P}{N P E N S}}{\frac{G D P}{L}}=\frac{N P E N S}{L} \frac{A V P E N S}{Q}=N P E N S P W * G E N Q
$$

where NPENS is the number of currently payable pensions and $L$ total employment. Hence, the fraction of GDP that is spent on pensions is equal to the number of pensions per employed worker (NPENSPW) multiplied by an indicator (GENQ) of the "generosity" of the average pension as measured by the ratio between this variable (AVPENS) and average labor productivity $(Q)$. It is useful to rewrite the first term of the decomposition as follows:

(2) NPENSPW $=\frac{N P E N S}{L}=\frac{N P E N S}{N R E T} \frac{N R E T}{N W A} \frac{N W A}{L}=C O V^{*} D E P * E M P$

where NRET and NWA denote, respectively, the population that has reached the age of retirement - currently 65 years - and the working-age population, which we will identify for now as that between the ages of 18 and 64 . Hence, the number of pensioners per employed worker can be expressed as the product of three factors: the rate of pension coverage ( $\mathrm{COV}=$ number of pensions per person of retirement age), the old-age dependency rate ( $D E P=$ number of potential pensioners per working-age person) and the inverse of the employment rate of the working-age population (EMP). Combining (1) and (2), we end up with:

(3) $\frac{P E X P}{G D P}=D E P * E M P * C O V * G E N Q$

\subsection{A simple model of pension expenditure}

De la Fuente (2011) develops a simple accounting model of aggregate pension expenditure in an economy with exogenous wages and employment. The model uses highly simplified assumptions, including non-stochastic lifespans and constant rates of growth of employment and productivity, ignores the heterogeneity of agents within each cohort and the endogeneity

${ }^{6}$ This type of decomposition has been used frequently in the literature. See, among others, Jimeno, Rojas and Puente (2008) and Doménech and Melguizo (2008). 
of decisions to enter or exit the labor market and does not take into account some important features of the Spanish system, including the existence of caps and floors on contributory bases and pension amounts. While some of these assumptions are likely to be innocent simplifications that help keep the required calculations tractable at little or no cost, others may bias the model's predictions in ways that are hard to predict ex-ante and do render it of limited usefulness for the analysis of certain types of policy changes or for the study of the distributional implications of pension reform. In spite of its highly stylized character, however, the model should be able to capture correctly the effects on aggregate pension expenditure of changes in the system's main parameters and in some key demographic variables. This makes it a useful complement of the decomposition described in the previous section, among other things because it imposes a certain discipline on projections of the evolution of the generosity of the system (the ratio between the average pension and average productivity), which is the component of pension spending that is hardest to model directly.

The model assumes that the pension calculation period $(N)$, the average number of contribution years of the representative pensioner (C) and the period during which retirement and survivors' benefits are collected ( $X$ and $X 2)$ are equal for all agents in each cohort and remain constant over time. ${ }^{7}$ It also assumes constant rates of growth for employment $(n)$ and average wages $(g)$, an experience premium that grows exponentially with time (also at a constant rate $v$ ) and a fixed rate of social security contribution $(\tau) .{ }^{8}$ For given values for these parameters and applying current Spanish regulations, the model can be used to compute the ratio between the average pension and the average salary, the internal rate of return (IRR) of the contributory pension system, the system's total revenues and expenditure and, hence, its financial balance, the average initial replacement rate (defined as the ratio between the initial pension and the wage at retirement) and the sustainable value of this ratio.

For the purposes of the exercise in this paper, the result of greatest interest is the one that links the system's generosity to the parameters used in pension calculations and to some demographic indicators. In particular, the ratio between the average pension (considering both retirement and survivors benefits) and the aggregate average salary is given by ${ }^{9}$

$$
\text { (4) } G E N W \equiv \frac{\bar{P}}{\bar{W}}=\phi(C) b(N) e^{v C} \frac{n-v}{g+n} \frac{1-e^{-n C}}{1-e^{-(n-v) C}} \frac{1-\left(1-\pi \phi_{v}\right) e^{-(g+n) X}-\pi \phi_{v} e^{-(g+n)(X+X 2)}}{1-(1-\pi) e^{-n X}-\pi e^{-n(X+X 2)}}
$$

where

\footnotetext{
7 This condition will be met if life expectancy and the ages of retirement and entry into the labor market remain constant over time or rise at the same pace.

${ }^{8}$ In response to a referee's query, it should perhaps be noted that the model does allow for different degrees of indexing of pensions to consumer prices. It is shown numerically in de la Fuente (2011) that higher indexing implies a higher steady state generosity ratio. In any event, indexing plays no role in our results since the Spanish system provides in principle for full indexing of pensions and this has not been affected by the recent reform.

${ }^{9}$ Economy-wide aggregates are calculated by integrating over the relevant cohorts, which is a relatively simple exercise under the assumptions of the model. For more details, see de la Fuente (2011).
} 


$$
\text { (5) } b(N)=\frac{1-e^{-(g+v) N}}{(g+v) N}
$$

is the so called regulatory base of the pension (expressed as a fraction of the wage at the time of retirement), $\phi(C)$ the percentage of the regulatory base that will be paid as pension to a retiree who has contributed to the system during $C$ years, $\pi(=1 / 2)$ the probability that a retiree will leave behind a spouse entitled to a widower's pension and $\phi_{v}(=0.52)$ the fraction of the deceased spouse's pension at the time of death that is paid out as widower's pension. In what follows, we will assume that the share of labor in GDP $\left(\alpha_{L}\right)$ remains constant. This implies that the steady-state value $\overline{G E N Q}$ of the generosity indicator that appears in the decomposition given in the previous section (the average pension as a fraction of average output per worker) will be a constant fraction of the ratio given in (4), that is:

(6) $\overline{G E N Q}=\frac{\bar{P}}{Q}=\frac{\bar{P}}{\frac{\alpha_{L} Q}{\alpha_{L}}}=\alpha_{L} \frac{\bar{P}}{\bar{W}}=\alpha_{L} \overline{G E N W}$

\section{Parameterising the model}

When using the model in combination with our demographic and employment scenarios, we must bear in mind that this is essentially a steady state model that cannot describe the transitional dynamics induced by changes in parameter values and can only capture their long-term effects. Consequently, we will set the values of the model's parameters taking as a reference the average values of the relevant variables that have been observed during (or are foreseen for) each period of interest. In particular, we will work with two different periods: the years between 1981 and 2007, which we will use as a reference to set certain parameter values, and the period between 2010 and 2060, for which we will construct spending and revenue projections with and without the recent reform.

Table 1: Parameterization of the model in different scenarios

\begin{tabular}{|c|c|c|c|}
\hline & [1] & [2] & [3] \\
\hline & $1980-2007$ & $\begin{array}{l}2010-60 \\
\text { no changes }\end{array}$ & $\begin{array}{c}2010-60 \\
\text { with reform }\end{array}$ \\
\hline Growth of labor productivity $(\mathrm{g})$ & $1.13 \%$ & $1.13 \%$ & $1.13 \%$ \\
\hline Total employment growth (n) & $1.90 \%$ & $0.24 \%$ & $0.26 \%$ \\
\hline Experience premium (v) & $1.28 \%$ & $1.28 \%$ & $1.28 \%$ \\
\hline Average employment rate (working-age pop.) & $56.03 \%$ & $68.23 \%$ & $65.90 \%$ \\
\hline Average years of contribution $(C)$ & 26.34 & 32.07 & 32.29 \\
\hline \multicolumn{4}{|l|}{ Life expectancy } \\
\hline For the entire population & 76.66 & 85.9 & 85.9 \\
\hline Male & 73.37 & 83.5 & 83.5 \\
\hline Female & 79.93 & 88.3 & 88.3 \\
\hline$X=$ collection period of retirement pension & 11.66 & 20.90 & 19.90 \\
\hline $\mathrm{X} 2=$ additional years of survivors' benefit & 6.02 & 5.15 & 5.15 \\
\hline Retirement age & 65 & 65 & 66 \\
\hline
\end{tabular}


Table 1 summarizes the relevant data. For 1980-2007, $g$ and $n$ are set equal to the average rates of growth of output per (full-time equivalent) employed worker and of total employment according to the Spanish National Accounts (INE, 2011a). The two rates are calculated by regressing the logarithm of the corresponding variable on a linear trend. Regarding labor productivity, our assumption for 2010-2060 is that the average growth rate observed in 19802007 will remain constant in the future. In the case of employment, the value of $n$ for the period 2010-2060 under each scenario $s$ - with or without reform - is set equal to the expected growth rate of employment during the period according to the employment projections discussed later on. This variable is calculated directly, rather than estimated econometrically, using observed current employment and the expected value of the same variable in 2060

$$
n^{s}=\frac{\ln L_{2060}^{s}-\ln L_{2010}^{s}}{50}
$$

where $L_{t}^{s}$ is expected employment in period $t$ under scenario $s$.

The average years of contribution by the representative retiree are estimated as the product of the average employment rate of the working-age population in the relevant scenario, (calculated as the average of its annual values) and the maximum theoretical duration of the working life of an individual, $65-18=47$ years. ${ }^{10}$ The average duration of a retirement pension $(X)$ is approximated as the difference between the average life expectancy of the population as a whole (using, once again, the average during the relevant period) and the retirement age, which we set equal to the legal age of 65 during the pre-reform period. Since, as we have seen, the reform contemplates significant exceptions to the new retirement age of 67 , for purposes of calculating $X$ during the post-reform period, we will set the average retirement age to 66 years. The collection period of a survivors' pension (X2) is taken to be the difference between the life expectancy of women and that of the population as a whole, plus 2.75 years, which is the average age difference between men and women at the time of marriage according to INE's marriage statistics (2011c). For 1980-2007, we use the average of life expectancy at birth in 1975 and in 2005. For 2010-2060, we use the average of the 2005 and 2060 values of this variable. The second figure is estimated by adding to life expectancy in 2005 the increase in the same variable forecasted by Eurostat in its 2008 population scenario (on which our projections are based).

The value of the experience premium $(v)$ is chosen so that the model reproduces the average initial replacement rate (that is, the ratio between the initial pension and the salary at the time of retirement) observed among new retirees who entered the system in 2008, as estimated by Devesa (2009, p. 64) using the panel of work histories put together by the Spanish Ministry of Labor (the so called "Muestra Continua de Vidas Laborales"). Finally, the social security contribution rate is assumed to be equal to $95 \%$ of the contribution rate for common

10 In scenarios [1] and [2], the working age population is identified with the population between the ages of 18 and 64, while in scenario [3] the population aged 18 to 66 is used. In the latter case, the average years of contribution are approximated by multiplying the employment rate of the relevant age group by $67-18=49$ years of potential working life. 
contingencies under the so called General Regime to which most salaried workers belong, calculated as the sum of the rates applicable to companies $(23.6 \%)$ and to workers $(4.7 \%) .{ }^{11}$

\subsection{Approximating the system's dynamics}

If the growth rates of productivity and employment and the parameters used in the pension calculation remain constant for a sufficiently long period, the generosity indicator of the system will gradually approach the value predicted by the model outlined in the preceding section. As we have seen, the model cannot be used directly to project the evolution of GENQ on a yearly basis, but it can be used to calculate its long-term value (conditional on constant growth rates of certain aggregates). This, in turn, will allow us to approximate the system's dynamics in a way that should be sufficient for our purposes.

For short, let $y$ be the logarithm of GENQ and let us assume that the parameters of the pension system and the rates of growth of productivity and employment remain constant for a long period of time. Since we know that $y$ tends to converge to the long-term value given in (6),

$$
\bar{y}=\ln \overline{G E N Q} \text {, }
$$

it seems reasonable to assume that the trajectory of this variable can be approximated by an expression of the form

$$
\text { (7) } \Delta y_{t}=-b\left(y_{t}-\bar{y}\right)
$$

where $b>0$ is the rate at which the system converges towards its long-term equilibrium.

What would a reasonable value for $b$ be? If we take the model literally - and accept, in particular, the assumption that all agents in a cohort have lives of the same non-stochastic duration - the transition to a new steady state after any parametric change should be nearly complete after $X$ years (where $X$ is the difference between life expectancy and the retirement age) given that, after this period, all individuals whose pensions had been set prior to the reform of the system will be dead. While some widows from the "old regime" will remain in the system for a few years, their weight in total expenditure will be small, because not all pensioners leave a widower behind and because widower pensions are much smaller than retirement pensions. The weight of widowers will be particularly small when the number of retirees is growing over time and when productivity, and hence the average pension, is also growing.

In practice, of course, the transition will be a bit slower than in the case we have just described because some of the pensions granted under the old regime will be collected for more than $X$ years, but it is still true that the bulk of the transition should have been completed in that time. Therefore, a reasonable assumption that can be used to set the value of $b$ may be that after $X$ years $75 \%$ of the initial distance of $y$ from its steady-state value will have disappeared.

\footnotetext{
${ }^{11}$ See section 1 of the Appendix.
} 
The solution to the difference equation given in (7) can be written

$$
\text { (8) } y_{t}-\bar{y}=\left(y_{o}-\bar{y}\right) *(1-b)^{t}
$$

where $y_{o}$ is the initial value of the (log of) the generosity indicator at the time of the system's reform and $t$ the time elapsed since then. Our assumption on the speed of adjustment is that after $X$ years only $25 \%$ of the initial distance from the steady state will remain, that is, that

$$
\text { (9) } y_{X}-\bar{y}=0.25 *\left(y_{o}-\bar{y}\right)
$$

Substituting (9) into (8) evaluated at $t=X$, we have

$$
\text { (10) } y_{X}-\bar{y}=\left(y_{o}-\bar{y}\right) *(1-b)^{X}=0.25 *\left(y_{o}-\bar{y}\right)
$$

Operating on this expression, we have

$$
(1-b)^{X}=0.25 \Rightarrow \ln (1-b)=\frac{1}{X} \ln 0.25 \Rightarrow b=1-\operatorname{Exp}\left(\frac{\ln 0.25}{X}\right)
$$

With the value of $X$ corresponding to the baseline scenario for 2010-2060 (20.9 years), this expression yields a value of $6.42 \%$ for the convergence parameter, $b$.

\section{Baseline scenario: expenditure and net balance projections in the absence of reforms}

This section describes the construction of the baseline or no-policy-change scenario. We have projected the evolution of pension expenditure in the absence of reforms by making minor adjustments to the baseline scenario set forth in de la Fuente and Doménech (2010). Our point of departure is the demographic projections recently constructed for Spain by Eurostat (Europop 2008). Eurostat's baseline scenario for Spain assumes a gradual decline in net immigration from more than 600,000 people in 2008 to a bit over 150,000 a year starting in 2040, a mild recovery in the birth rate from 1.39 children per woman in 2008 to 1.56 in 2060 and a rapid increase in life expectancy of 7.5 years for men and 5.7 years for women over the same period. ${ }^{12}$ With these assumptions, the aging process will be quite rapid: the old-age dependency rate (defined as the quotient between the $65+$ population and the population aged 18-64) will rise sharply over the next five decades, rising from 0.25 in 2008 to 0.62 in $2060 .^{13}$

\footnotetext{
12 Eurostat has just released a new population projection (Europop 2010). We have been unable to use it as a basis for our calculations because Eurostat's website only provides data at five-year intervals and only disaggregates the population by 5 -year age segments. The new Eurostat scenario and its predecessor share very similar assumptions regarding the evolution of fertility rates and life expectancy and differ mostly on the expected time profile of migration. While expected average yearly net inflows over the period remain almost unchanged, Europop 2010 assumes a hump-shaped pattern of this variable, which gradually recovers from rather low levels during the current crisis before declining again gradually after 2020. As a result, Europop 2010 projects a more rapid increase in the dependency rate until 2040 or so and a slower one after that date, with this variable reaching a lower peak a bit earlier than expected in the earlier exercise. For more details, see section 2 of the Appendix.

13 In general, Eurostat's 2008 scenario is more optimistic than INE's most recent long-term projections (INE, 2010), although not in every respect. INE estimates a net migratory inflow of roughly 50,000 people per year for 2009-2018 and roughly 70,000 for 2019-2048, which is far below Eurostat's projection. On the other hand, INE is somewhat more optimistic than Eurostat regarding the recovery of the birth rate. In 2048, the Institute expects a birth rate of 1.71 children per woman, compared with the 1.52
} 
According to the National Statistical Institute's current population projections (INE, 2011b), the growth of the Spanish population between January 2008 and the same month of 2011 was below Eurostat's projections, probable due to the effects of the current crisis on fertility and on inmigration. In order to base our population series on the latest observed values of this variable, we have modified Eurostat's population scenario in the simplest possible way: for each age segment of interest, we take as a given the population estimate as of January 1st 2011 provided by INE and we extend the series forward to 2060 using the growth rate of the same population segment in Eurostat's original 2008 baseline scenario.

We have also introduced minor changes in the employment projections reported in our earlier paper while maintaining the rather optimistic long-term assumptions on which our baseline scenario was based. The change has to do with the evolution of employment until 2015, which has been adjusted in two respects. First, we have used the observed values of this variable between 2008 and 2010 (taken from the Nacional Accounts and measured by full time equivalent employment). ${ }^{14}$ Second, we extend the series until 2015 by using the macroeconomic baseline scenario of BBVA Research as of June 2011. From 2015 onward, the assumption of the previous paper is maintained, namely, that the employment rate of the population aged 18 to 64 will converge, at an annual rate of $4 \%$, to the employment rate of Spanish men aged between 16 and 64 in 2007 (77.4\%), which is quite close to the employment rates (defined as the ratio of employment to the working-age population) of Japan, the Nordic countries, Canada or the US.

Figure 2: Projection of the number of pensions per employed worker in the absence of reforms

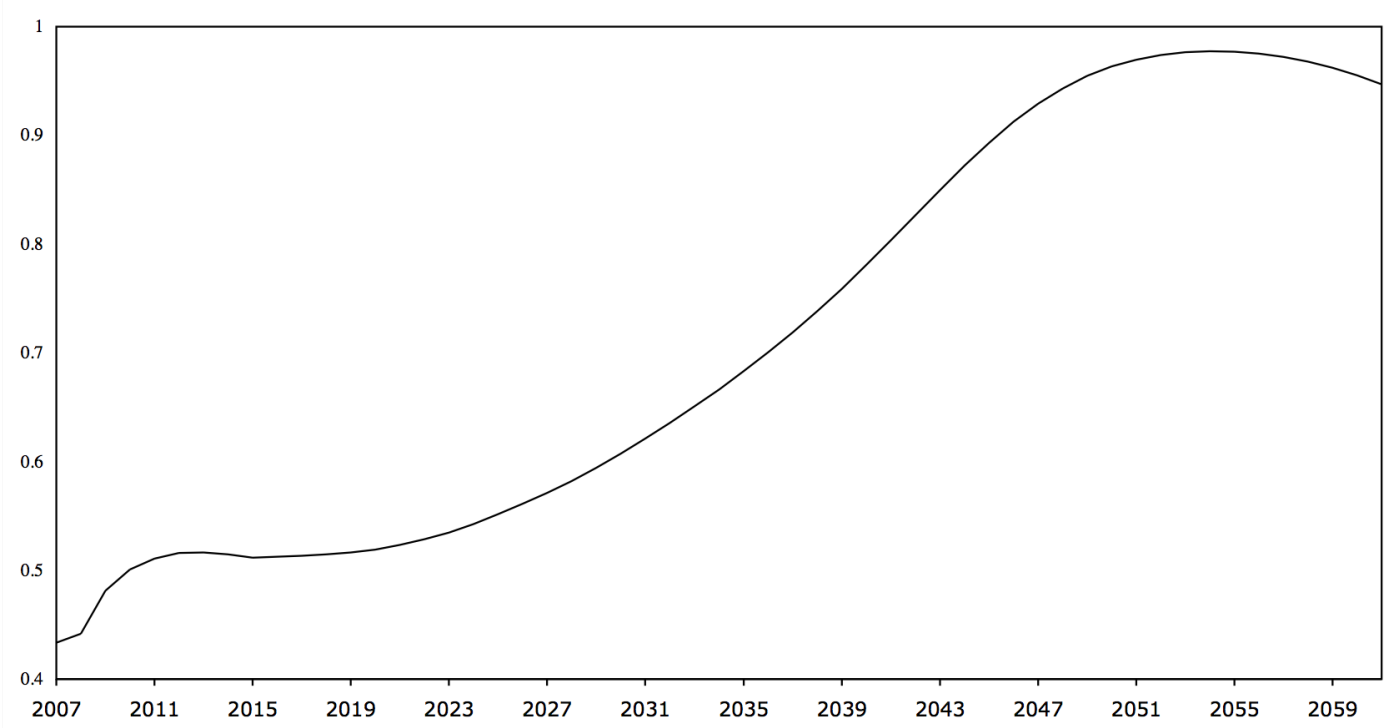

By adding to these premises the assumption that the coverage rate (defined as the number of pensions per person of retirement age) remains constant at its observed level in 2010 (which

estimated by Eurostat for the same year. Finally, the anticipated increase in life expectancy is greater in the INE scenario. According to the Institute, life expectancy at birth in 2048 would be 84.31 years for men and 89.89 years for women, compared with 83.4 and 88.4 years according to Eurostat.

14 The figures for 2010 are taken from the Quarterly National Accounts. 
was 1.12), we can project the evolution of the number of pensions per employed worker (NPENSPW), which is the first component of the ratio of pension expenditure to GDP. Figure 2 shows the evolution of this ratio under the assumptions listed above and in the absence of reforms to the pension system. The high rate of growth of this indicator observed in 20072010 is largely due to cyclical reasons, and particularly to the rapid job destruction we have experienced during the current crisis. The growth of this ratio can be expected to decline somewhat in the near future before rising again sharply in the next decade, this time due to structural causes having to do with the retirement of the baby boom generation.

Minor changes from our previous paper have also been made in the modeling of the evolution of the system's generosity ratio. In particular, while we maintain the procedure used to estimate the long-term value of this variable, our assumptions regarding the system's transitional dynamics have changed. In our previous paper we assumed a linear transition between the last observed value of GENQ and the model's steady-state prediction that would be completed in 2060. In this paper, the transition is modelled using the methodology described in the preceding section and the steady state is attained only asymptotically.

Table 2 Estimated steady-state values for the $\bar{P} / \bar{W}$ ratio

\begin{tabular}{lcr}
\hline & $\begin{array}{c}\text { Estimated } \\
\text { value }\end{array}$ & \multicolumn{1}{c}{ index } \\
1980-2007 & 0.704 & 100.0 \\
$2010-2060$, no reform & 0.809 & 115.0 \\
$2010-2060$, with reform & 0.700 & 98.3 \\
& & \\
\hline
\end{tabular}

The method used to estimate the steady state has not changed. Using equation (4) and the parameter values given in Table 1, we have calculated the steady-state values of the $\bar{P} / \bar{W}$ ratio predicted by the model (see Table 2). The observed value of this ratio in 2007 (using data on retirement pensions of the general regime) is 0.51 , which is substantially lower than the model's prediction. If the model were correct, this would indicate that we are still far from the steady state and that the upward trend of $\bar{P} / \bar{W}$ that we observe in recent decades would persist in the future even if all system parameters remained constant indefinitely at the values we observed during 1980-2007. Further, the model's prediction for the $\bar{P} / \bar{W}$ ratio in the absence of reforms is higher for 2010-2060 than for 1980-2007, mainly due to the increase in average years of contribution implied by our optimistic employment scenario. Striving to be conservative, we will not directly use the model's prediction for the steady-state value of the $\bar{P} / \bar{W}$ ratio. Instead, we will assume that in 2007 the system was in the steady state corresponding to the parameters of the 1980-2007 period and that the steady-state value for the $P / W$ ratio will increase in the same proportion as the model's prediction for 2010-2060 in relation to the prediction for 1980-2007. That is, for each scenario, the steady-state value of $\bar{P} / \bar{W}$ for $2010-2060$ is estimated by multiplying the observed value of this ratio in 2007 by the index in the second column of Table 2. Finally, we will assume that the share of wages in national income remains constant over time. This implies that the long-term generosity ratio, 
measured in terms of the average productivity of labour, GENQ, will also increase in the same proportion.

Figure 3 shows the expected path of the generosity indicator in the absence of reforms. Combining this variable with the NPENSPW projection described above yields the projection of total expenditure shown in Figure 4.

Figure 3: Projection of the generosity ratio (average pension/GDP per employed worker)

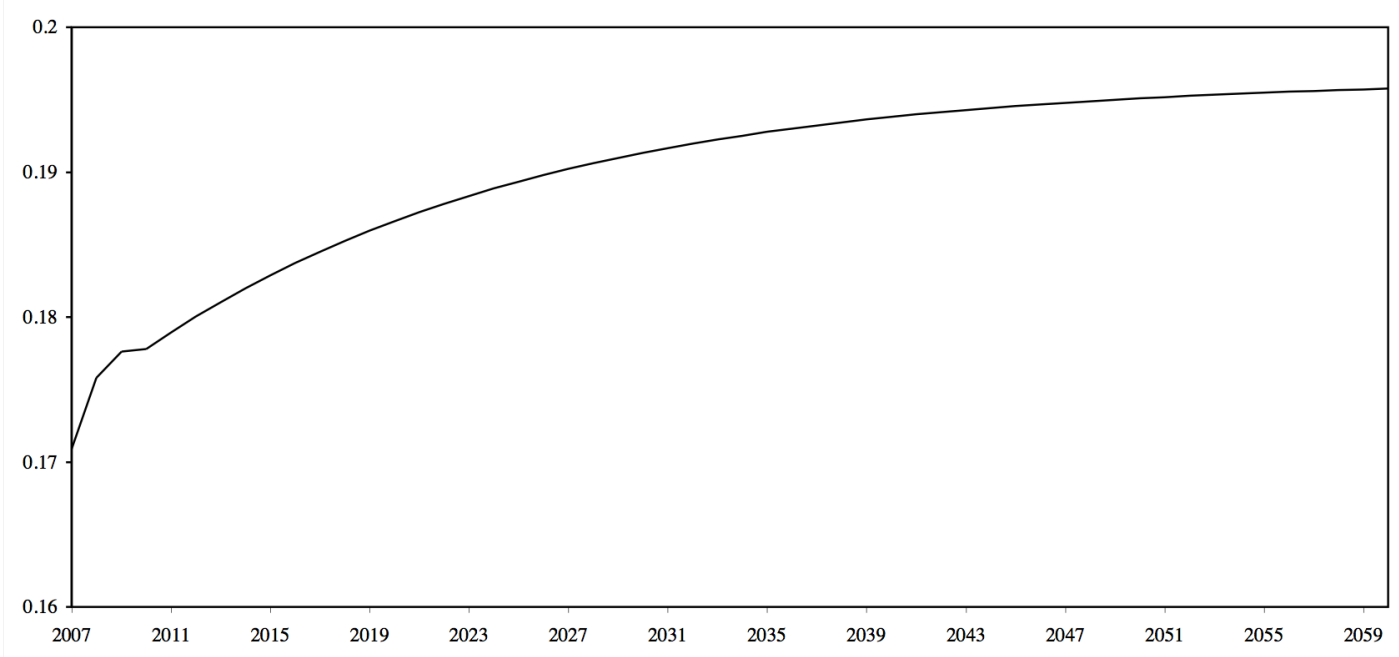

Figure 4: Projection of pension expenditure as a percentage of GDP

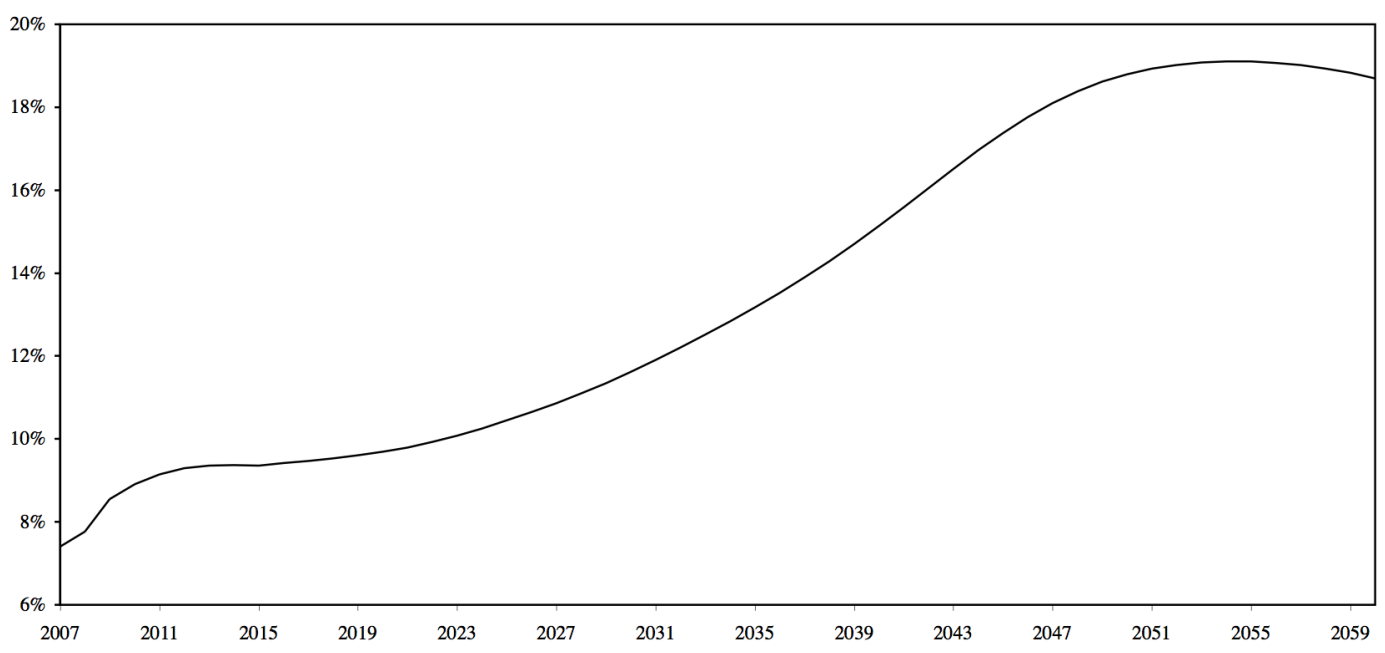

We have also projected the evolution of the system's revenues and the balance of the Pension Reserve Fund (PRF) over the period of interest. Since Social Security contributions are levied at a fixed rate on wage income (subject to a ceiling and a cap), it seems reasonable to assume that, as a first approximation, contribution revenue will remain constant over time as a fraction of the aggregate wage bill and of GDP. Starting from this assumption, we have introduced a minor correction to account for the increased State contribution to the financing of minimum pension complements that is mandated by law (see section 1 of the Appendix). With this correction, we project the pension system's revenues as a fraction of GDP to rise 
from $9.12 \%$ in 2010 to $9.52 \%$ in 2017 and to remain constant at that level thereafter. Under these assumptions, which are relatively optimistic, the system would experience a permanent deficit from 2019 onward. If we assume that the minor surpluses accumulated during some of the earlier years are deposited in the Pension Reserve Fund (PRF) and that this Fund earns a real annual return of $2 \%$, the PRF would run out in 2027. After this point, the system's debt would balloon in the absence of policy changes, reaching 250\% of GDP in 2060 (again assuming a real rate of return of $2 \%$ ).

\section{The financial effects of the reform: a quick estimate}

The impact of the measures described in section 2 on the number of pensions per employed worker is easily calculated with a few additional assumptions. Increasing the retirement age will reduce the number of pensioners and increase the number of employed persons. To quantify the effects of this measure, we have ignored the possibility of early retirement and assumed that those affected by the increase in the retirement age have an employment rate that is similar to that of the population aged between 60 and 64 years in the year 2007 (which was $33 \%$ ). In order to account for the exceptions to the rising of the retirement age, we will assume that only half of the potentially relevant population is actually affected by this measure.

Figure 5: Projection of employment and retirement-age population, with and without reform $(2007=100)$

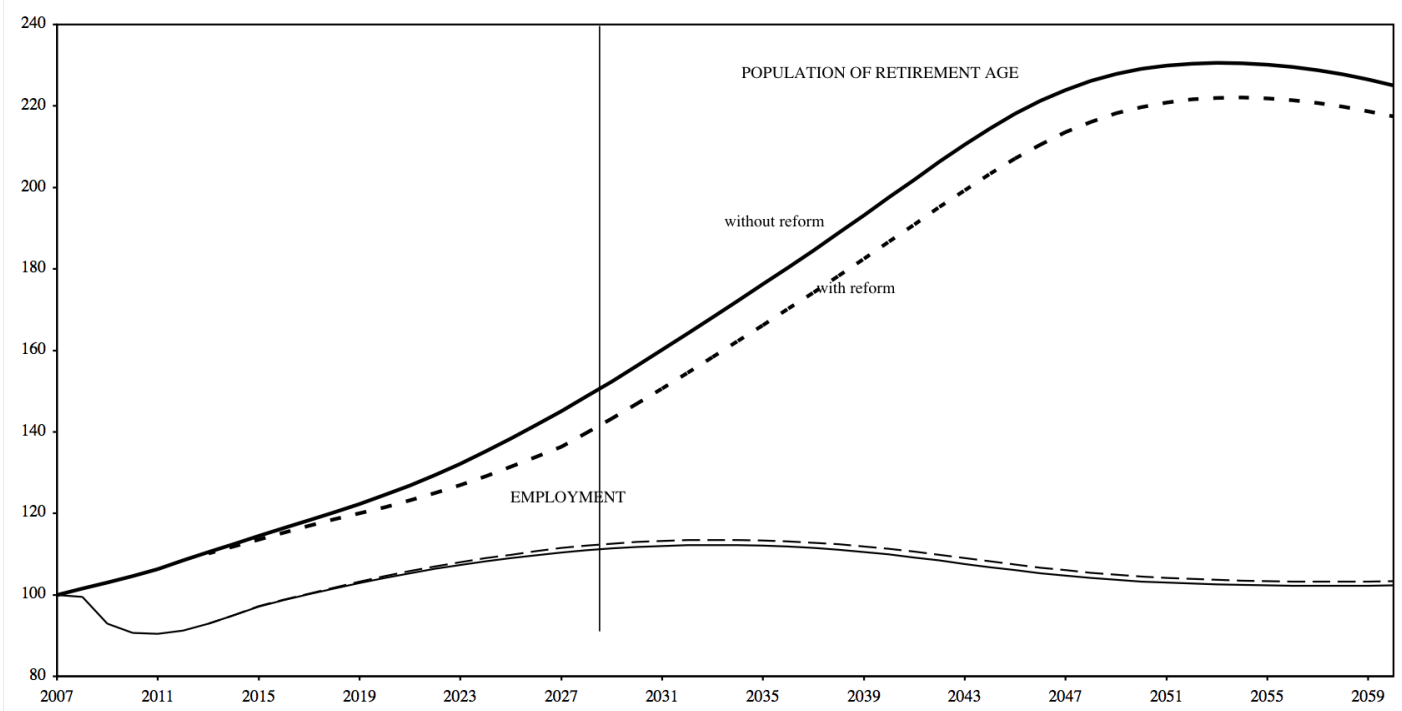

Figure 5 shows the implications of the reform for the evolution of employment and the retirement-age population and Figure 6 summarizes its estimated impact on the number of pensions per employed worker. Under our hypotheses, the gradual rise in the retirement age will temporarily stabilize the ratio between pensioners and employed persons. Starting in the second half of the next decade, however, growth in the first variable surges, with dramatic effects on the first major component of pension expenditure. 
Figure 6: Projection of the number of pensions per employed worker

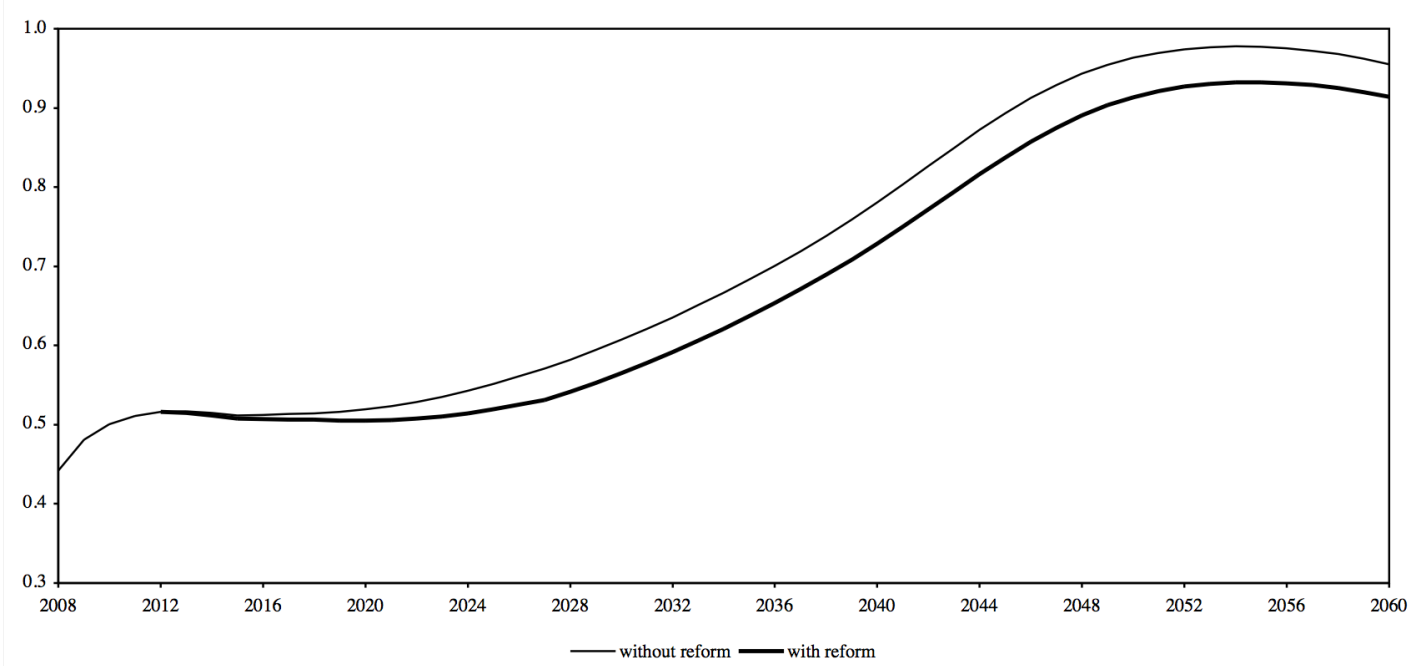

Figure 7: Evolution of the long-term generosity ratio with and without the reform

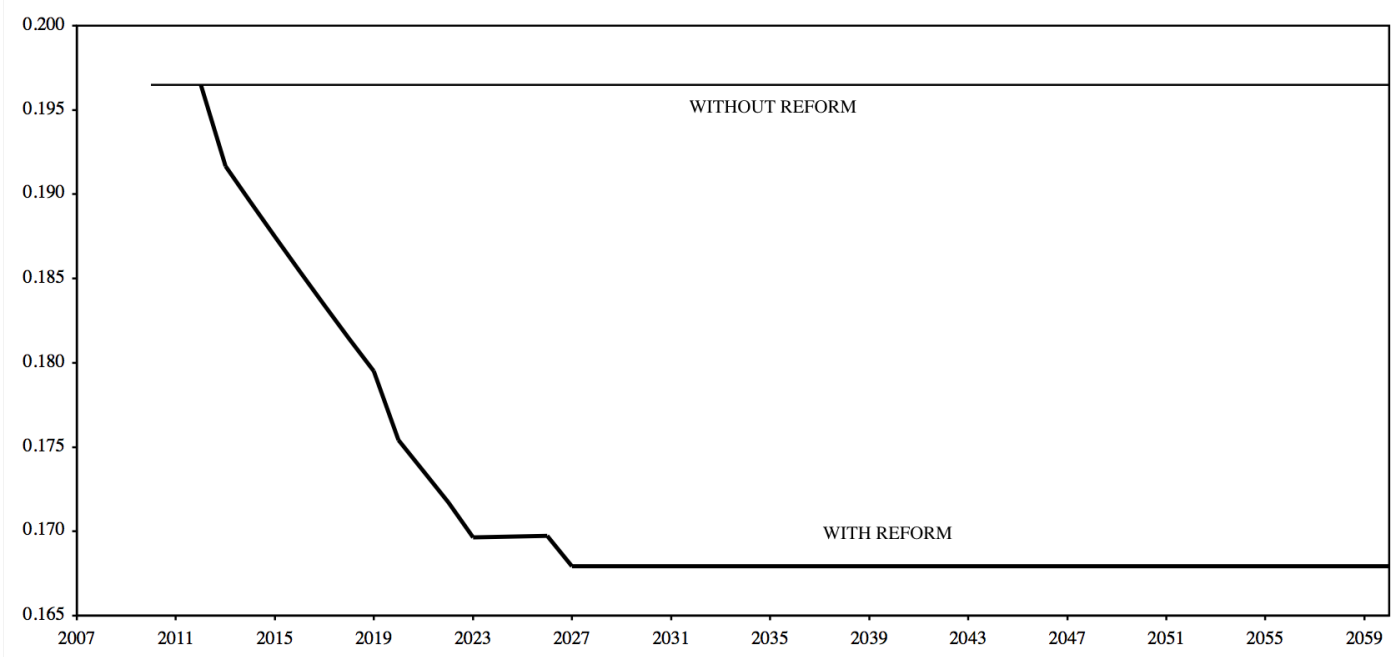

Projecting the evolution of the generosity ratio is somewhat more complicated than in the baseline scenario because of the gradual nature of the reform. For each transition year $t$ we have used the model outlined above to calculate the long-term generosity ratio $\bar{y}_{t}$ that would correspond to the parameters of the system at $t$, which would vary from year to year between 2012 and 2027. Figure 7 shows the time path of $\bar{y}_{t}$, which would gradually fall from 0.196 to 0.168 with the implementation of the reforms. Hence, the changes in the calculation procedure introduced in the new law will reduce the average pension (relative to the average wage) by $14.5 \%$ for a given time path of earnings and social contributions. ${ }^{15}$

15 Since wages are exogenous in our model, this figure is very close to the expected reduction in the pension of the average worker that would follow from the reform other things equal. Given our assumptions on the growth rate of wages over the lifecycle, an increase in the pension computation period from 15 to 25 years will reduce an individual's starting pension by $10.43 \%$. For an individual 
To approximate the system's year to year dynamics, we will proceed as above while allowing the steady state to vary over time. That is, we will assume that in year $t$ the value of the logarithm of the generosity ratio converges to its steady-state value for the same year and does so at the same rate we used in the previous section, in accordance with the following expression

$$
\text { (7') } \Delta y_{t}=-b\left(y_{t}-\bar{y}_{t}\right)
$$

which is identical to equation (7) except that $\bar{y}_{t}$ now has a time sub-index that tells us that the system is approaching a moving target during the transition period.

Figure 8: Projection of the generosity ratio of the pension system (average pension/GDP per employed worker) with and without the reform

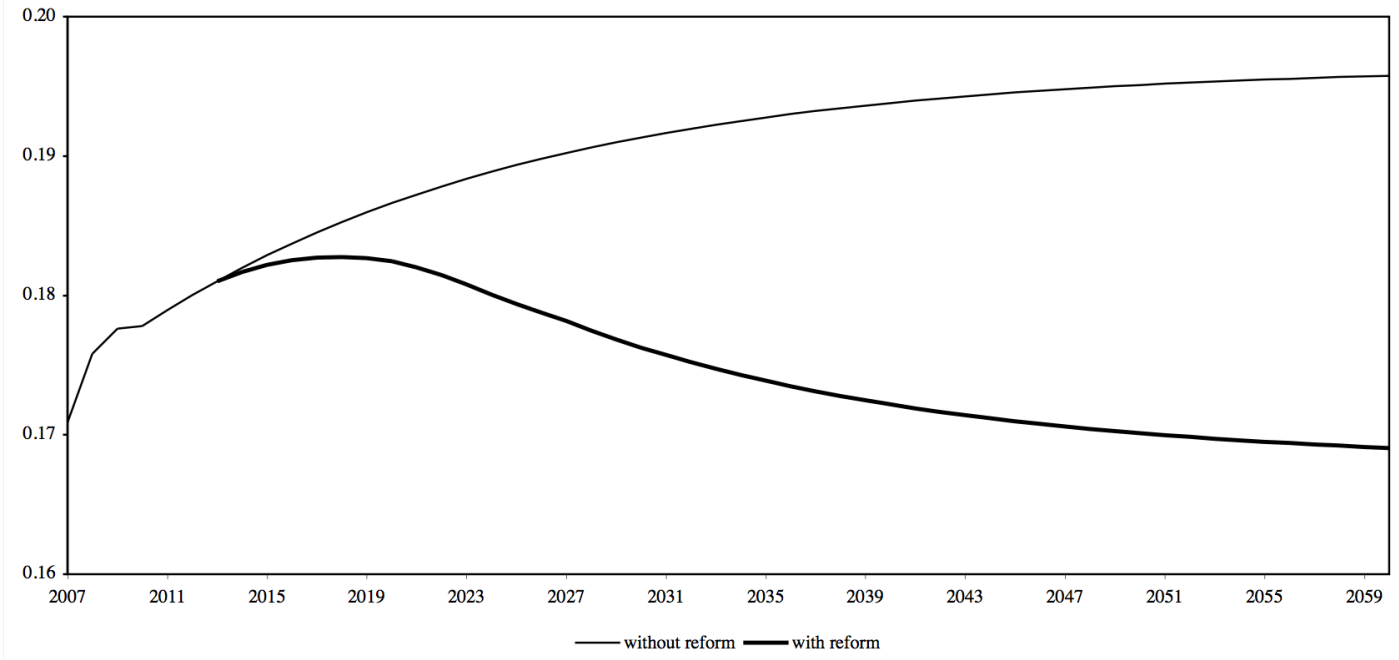

Figure 8 shows the estimated trajectory of the generosity ratio after the reform. Combining this projection with our prior estimate of the number of pensions per employed worker yields the spending projection summarised in Figure 9 and the estimate of savings arising from the reform that is shown in Figure 10 as a percentage of GDP and measured in Figure 11 by the percentage reduction in pension expenditure. Figure 10 also shows our estimate of how savings would have increased in the absence of the noted exceptions to the new retirement age and Figure 11 shows a decomposition of the reduction in expenditure into its three immediate sources. ${ }^{16}$ Looking at the last figure we see that in the long run the bulk of the

with 35 years of contribution, the change in the scale linking years of contribution to pension amounts will reduce his starting pension by $4.40 \%$. Both changes together will translate into a $14.37 \%$ reduction in the starting pension.

16 Given some variable of interest, $X$, let $X_{t}^{\text {ref }}$ and $X_{t}^{\text {noref }}$ denote its projected time path with and without the reform. The percentage change in the value of $X$ as a result of the reform can be approximated by

$$
\% \Delta X_{t}=\ln X_{t}^{r e f}-\ln X_{t}^{\text {noref }}
$$

Referring to equations (1) and (2) in section 2.1, observe that the ratio of pension expenditure to GDP can be written in the form 
Figure 9: Projection of pension expenditure as a percentage of GDP, with and without the reform

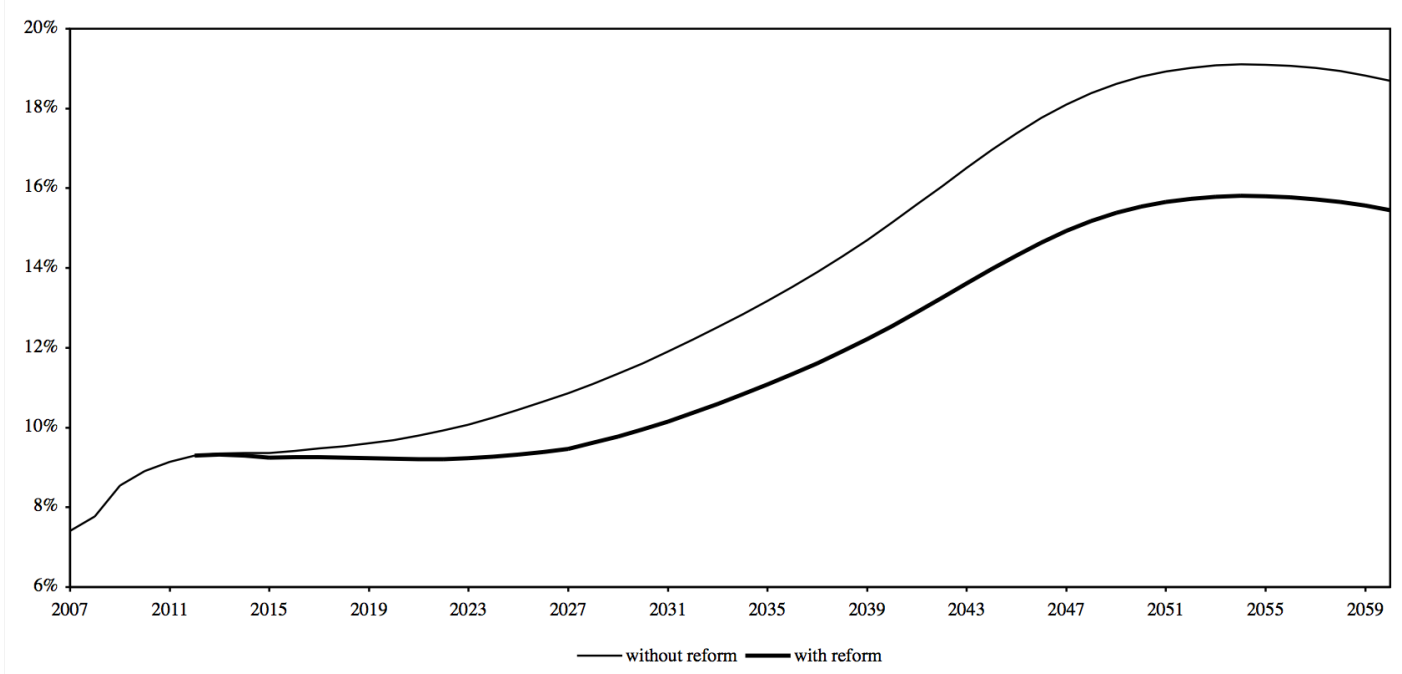

Figure 10: Savings resulting from the reform, in percentage points of GDP

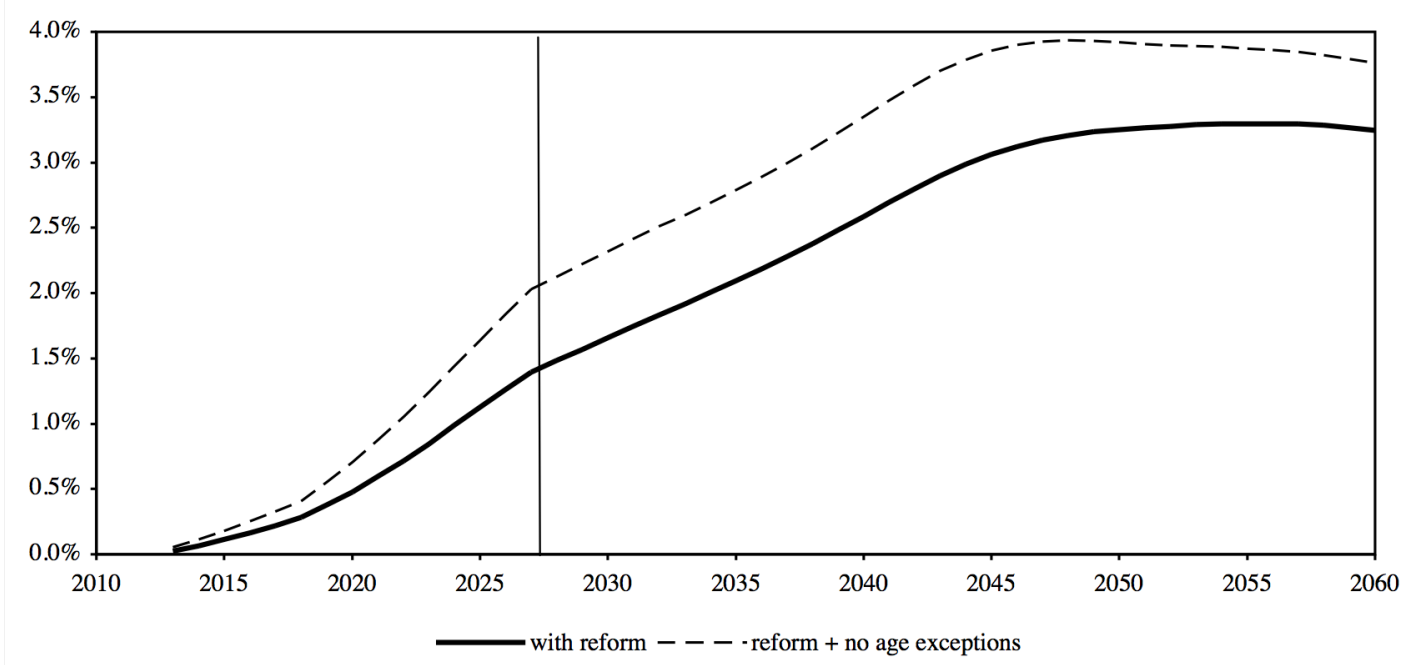

expected savings come from the reduction in the generosity of the system, whose effects build up gradually over time and converge asyntotically to the $14.5 \%$ steady-state reduction in this variable estimated above. The reduction in the number of retirees is also important during the transition years but gradually loses importance once the age of retirement stops rising.

$$
\frac{P E X P}{G D P}=C O V * \frac{N R E T}{L} * G E N Q
$$

Under our assumptions, the reform reduces the number of potential retirees, NRET, increases employment, $L$, and reduces the system's generosity factor, GENQ. Hence, the percentage change in expenditure, measured as a fraction of GDP, can be written as the sum of the contributions of these three factors, ie.

$$
\% \Delta \frac{P E X P}{G D P}=\% \Delta N R E T-\% \Delta L+\% \Delta G E N Q
$$

which is the formula used to construct Figure 11. 
Finally, the expected increase in employment is too small to have a significant effect on the spending ratio.

Figure 11: Percentage reduction in pension expenditure as a result of the reform and its immediate sources

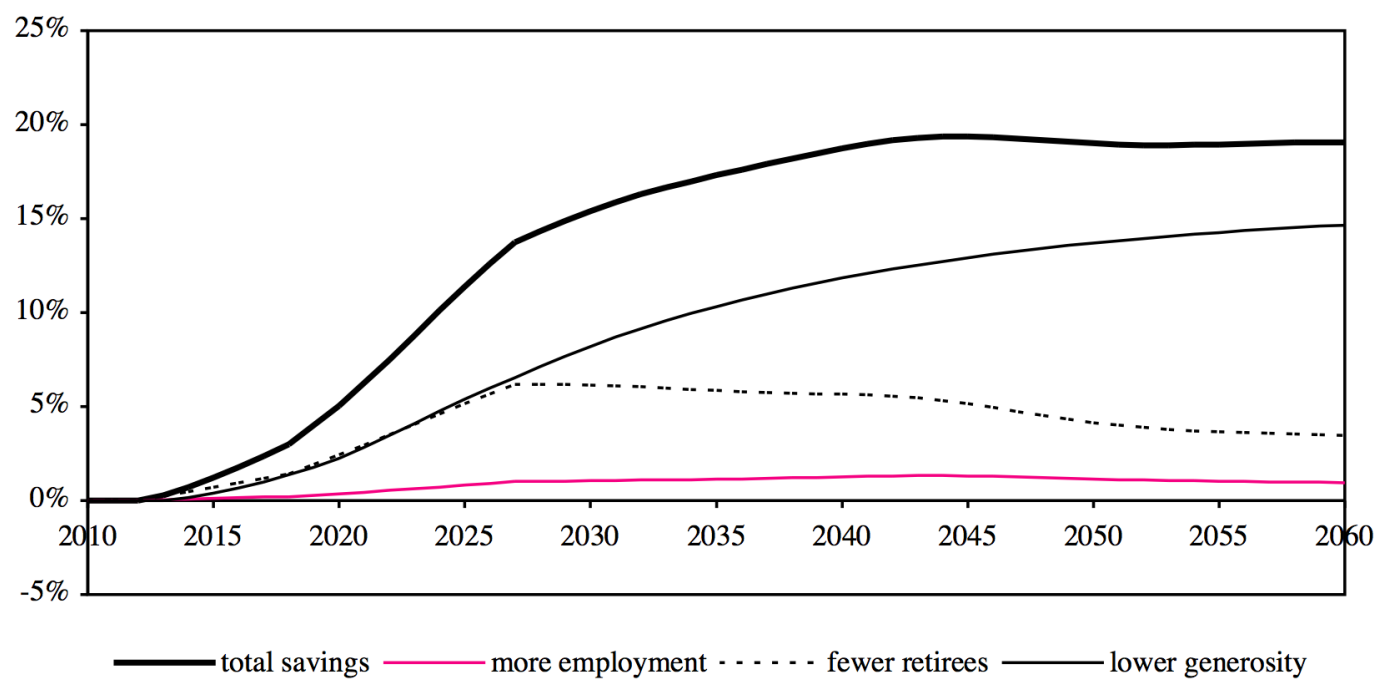

Figure 12: Projection of the Pension Reserve Fund/accumulated debt of the pension system as a percentage of GDP

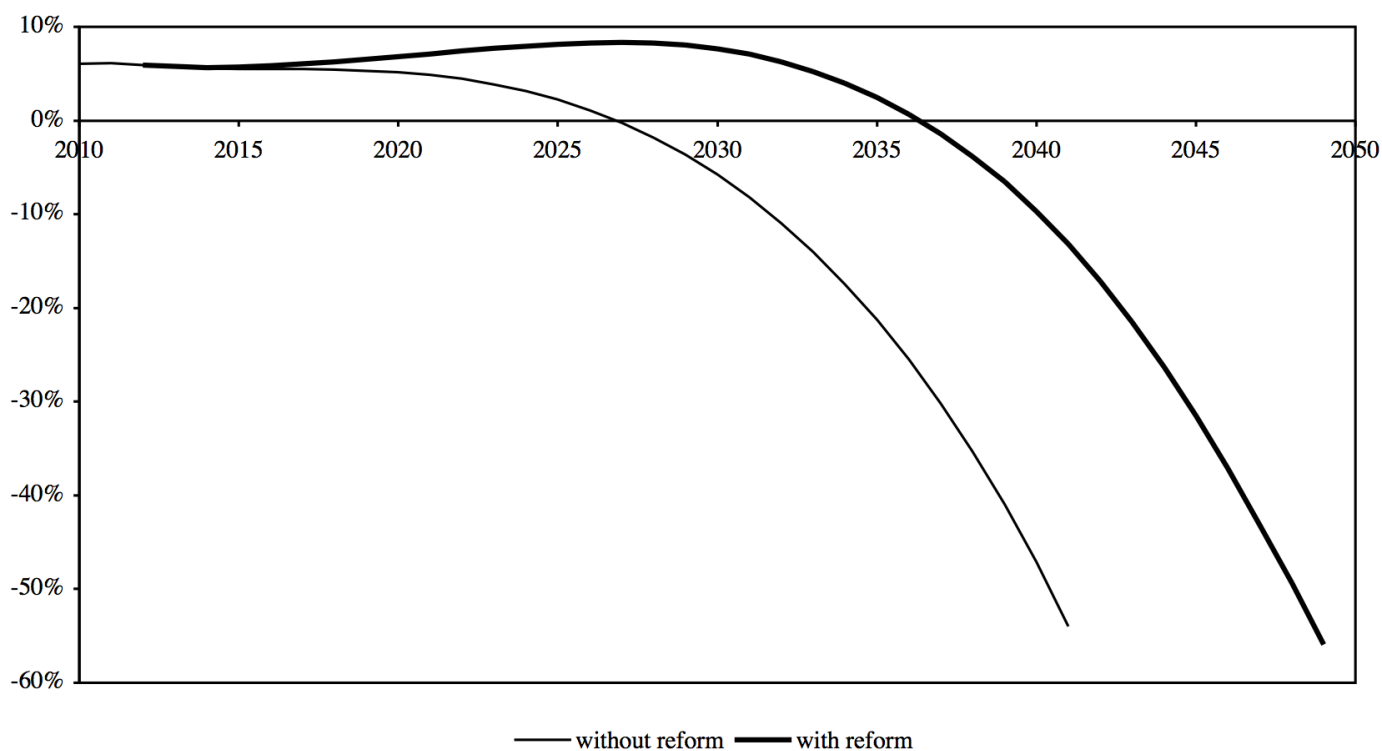

On the basis of our assumptions regarding the evolution of employment, productivity and demographics, the results of the analysis suggest that the proposed reforms would reduce pension expenditure by up to $20 \%$ by 2050 . Expected savings would amount to 1.4 points of GDP at the end of the transition period in 2027 and to 3.25 points by mid-century (which would increase to 2.0 and 3.8 points respectively without the approved exceptions to the new retirement age). In this scenario, the reform would suffice to stabilize pension expenditure as 
a percentage of GDP during the transition period. In the absence of further reforms, however, spending is projected to rise quickly starting in 2030 and to reach 15\% of GDP by 2050, thereby generating deficit levels that would be very difficult to sustain.

The implications of the reform for the financial balance of the system are summarized in Figure 12, which displays the expected evolution of the Pension Reserve Fund or the system's accumulated debt with and without the reform. As noted above, in the no-reform scenario, the PRF would run out by 2027. The reform would push this date back to 2037, giving us an additional decade to design and implement the additional measures that would be required to prevent the insolvency of the sytem during the 2040s. Eliminating the exceptions to the new retirement age would buy us five additional years before the PRF runs out.

\section{Comparison with other projections}

A number of other estimates of the effects of the recent reform are already available. The Spanish Ministry of Economics and Finance has included its own projections (with and without taking into account the so called sustainability factor) in the latest version of Spain's Stability Program for 2011-14 (MEH, 2011). These projections seem to have been accepted by the OECD and the IMF and have been included in their recent reports on pension systems in member states and on the situation of the Spanish economy (OECD 2011 and IMF 2011). The Ministry, however, gives few methodological details and reports only that its estimates have been based on INE's (2010) demographic projections and on a macro scenario consistent with the common methodology used by EU members for medium and long-term projections. The Bank of Spain has also included estimates of the savings derived from the reform in its recent annual report (2011), which have been obtained using an overlapping generation model and Eurostat's 2008 population projections. Some academic researchers have also studied the subject. Conde-Ruiz and Gonzalez (2011) analyze the effects of the reform using an accounting model with heterogeneous agents calibrated using data from the Labor Force Survey and the Continuous Sample of Working Lives and INE's (2005) long-term population projections. Finally, Díaz-Giménez and Díaz-Saavedra (2011) use a calibrated dynamic general equilibrium model and INE's 2010 population scenario to analyze the impact of two of the three key measures introduced in the recent law: an increase of two years in the retirement age and the extension of the calculation period from 15 to 25 years. Table 3 compares our estimates of the savings arising from the reform with those from other studies. As can be seen in the Table, our results lie almost exactly in the middle of the range of the available estimates when savings are measured in relative terms (as a fraction of the expected increase in pension expenditure in the absence of the reform) and at its upper end when savings are measured in absolute terms (as percentage points of GDP). While there are significant differences across estimates that are not always easy to trace back to primary

assumptions (because of the use of very different approaches and the limited methodological information that is provided in some cases) all the existing studies agree in qualitative terms and suggest that the recent reform will significantly reduce the growth rate of pension expenditure over the next four decades. 
Table 3: Alternative estimates of the savings derived from the reform

\begin{tabular}{|c|c|c|}
\hline & $\begin{array}{c}\text { in } \\
\% \text { points } \\
\text { of GDP }\end{array}$ & $\begin{array}{l}\text { as a \% of the } \\
\text { expected increase } \\
\text { in pension } \\
\text { expenditure w/o } \\
\text { the reform }\end{array}$ \\
\hline this paper & $3,25 \%$ & $33 \%$ \\
\hline MEH (2011) & $2,50 \%$ & $38 \%$ \\
\hline + sustainability factor & $3,50 \%$ & $53 \%$ \\
\hline Bank of Spain (2011) & $2,84 \%$ & $43 \%$ \\
\hline Diaz Giménez \& Diaz Saavedra (2011) & $2,77 \%$ & $30 \%$ \\
\hline Conde \& González (2011) & $2,87 \%$ & $29 \%$ \\
\hline average w/o sustainability factor & $2,85 \%$ & $34 \%$ \\
\hline
\end{tabular}

- Note: The second column is obtained by dividing the first one by the expected increase in pension expenditure in the absence of the reform until 2050. In the case of MEH (2011) and Bank of Spain (2011) this last magnitude is taken from the official estimates of aging-related expenditure prepared by the Economic Policy Committee of the EU. In our case and that of Conde and González (2011) we calculate it as the difference between projected expenditure in 2050 and observed expenditure in 2010 and in Díaz Giménez and Díaz Saavedra as the difference between projected expenditure in 2050 and in 2010.

\section{Conclusions}

This paper presents a preliminary estimate of the financial impact of the recent reform of the Spanish public pension system. After updating our earlier projections of spending on contributory pensiones during the period 2008-60 in the absence of reforms (de la Fuente and Doménech, 2010), we have estimated the impact on this variable of the three main measures included in the new law: increasing the retirement age to 67 with significant exceptions, extending the pension calculation period to 25 years and increasing to 37 the number of contribution years required to be entitled to $100 \%$ of the regulatory base.

Although reasonable doubts remain as to whether or not these measures will be sufficient to ensure by themselves the financial sustainability of the system, they do constitute a significant step in the right direction for three reasons. First, because they have triggered an important public debate about the sustainability of the public pension system that has not been restricted to the political parties. Second, because the agreement to raise the retirement age has broken a real taboo. Now that that barrier has been crossed, it will be much easier to deal with the further changes that may be required in the future to ensure the sustainability of the system. Lastly, and in line with the previous point, because the introduction of the sustainability factor entails a qualitative change in the nature of the system by introducing a quasi-automatic mechanism for making reforms that had previously required long gestation periods and laborious agreements.

Contingent upon certain assumptions about the evolution of employment, productivity and demographics, the results of this paper suggest that the three main reforms introduced in the new pension law will have a significant impact on expenditure and may be expected to yield savings of around 1.4 points of GDP at the end of the transition period in 2027 and of 3.25 points by mid-century. In this scenario, the reform would stabilize pension expenditure at a 
bit over $9 \%$ of GDP during the transition period, thereby preventing the emergence of a structural deficit in the system before the end of the next decade. In the absence of further reforms, however, we anticipate that expenditure will increase rapidly after 2030, reaching more than $15 \%$ of GDP by 2050 . Hence, additional reforms will be required in the future to prevent the emergence of large deficits.

Given the uncertainty that surrounds the projections of many of the variables of interest, we cannot rule out the possibility that, even with the reform, the system may begin to experience a structural deficit before the end of the transition period. Under these conditions, a sensible precaution would be to move up the introduction of the sustainability factor to the start of the reform, rather than waiting for the end of the transition period. This would activate a mechanism that could be used to modulate the pace and scope of the reforms, should the financial situation of the system so require before the end of the transition period. Further, it is clear that the financial health of the system depends not only on the evolution of life expectancy but also on other variables like the employment and dependency rates that influence the number of pensions per employed person. One important implication of this observation is that the sustainability factor cannot be linked only to life expectancy, as the wording of the law appears to indicate (BOE 2011, art. 8), but must also take into account other variables that are relevant for the financial health of the system.

In addition to any further parametric changes that should prove necessary in the future to ensure the sustainability of public pensions, it is very important to increase the transparency of the system by supplying additional information both to contributors and to pensioners. This would enable society to internalize the close relationship that exists between contributions and benefits and would help workers make timely and informed decisions regarding the best way to prepare for retirement. The experience of other European countries that have introduced models with notional accounts in their public pension systems, like Sweden, Italy, Poland or Latvia, should provide a useful reference in this regard. While stopping well short of this mark, the new law does take an important preliminary step in the correct direction by requiring both the Social Security system and the operators of private pension plans to provide their contributors or participants with information regarding their likely future pension rights (additional disposition no. 26). The provision is, however, rather vague and it remains to be seen how it will be implemented. 


\section{Appendix}

\section{Data on pension revenues and expenditures}

The expenditure data we use as a starting point for our calculations refer to spending on contributory pensions by the Spanish Social Security system. The Gazette of Labor Statistics (Boletin de Estadísticas Laborales) (MITIN, 2011a) provides data on the number of pensions paid every month (between 1988 and 2010) broken down by type of pension (retirement, disability, survivors' benefits, and benefits for orphans and other family members) and the average amount of each type of pension. ${ }^{17}$ Total pension expenditure is estimated by multiplying the average number of pensions payable in each year by their average annual amount (which is calculated as fourteen times the monthly amount). ${ }^{18}$ The calculation is done separately for each type of pension and the results are aggregated. We have checked that the total obtained in this way approximately matches the figure in the General State Budget for this item.

In Spain, contributions for common contingencies cover a series of contingencies in addition to retirement. As a result, it is not possible in principle to isolate a specific contribution to the pension system. On the basis of an internal Spanish Government report cited by Doménech and Melguizo (2008), we estimate that $95 \%$ of such contributions can be imputed to the pension system. To this, we must add a transfer from the State's General Administration to cover a growing fraction of the "minimum complements" that raise the lowest contributory pensions to the minimum set by law. Our data on the system's revenues are taken from the Economic and Financial Report of the General Social Security Budget for fiscal year 2011 and the Appendix to that document (MITIN, 2011b).

According to MITIN (2011b, pp. 54 and 185) in 2010 the system's total revenues amounted to 9.12\% of GDP. State contributions to minimum pension complements totaled 2.706,35 million euros, or $0.25 \%$ of GDP, which represented $38.8 \%$ of the total cost of the program (of 6.972,43 Meuros). The Social Security Law currently in force (transitory disposition no. 14 in BOE, various years) establishes that the State should pay the full cost of pension complements by 2014, but it is widely acknowledged that the current state of public finances will make it impossible to reach this goal on time. ${ }^{19}$ Trying to be realistic, we have assumed that the State gradually increases its contribution to the program starting in 2013 and starts covering its full cost (which is assumed to remain constant as a percentage of GDP) by the year 2017.

17 To calculate annual expenditure, we have taken into account the fact that pensions are paid out in fourteen installments per year, including extra payments in july and december.

18 The total number of pensions payable is greater than the number of pensioners because one person may have more than one pension.

19 In this regard, it is worth noting that the reform law contains only a vague compromise to work towards this goal, which is often known as "separation of sources" of financing. Its additional disposition no. 12 requires the Government to "seek formulas" to make fiscal consolidation and the separation of sources compatible with each other. 


\section{Europop 2008 vs. Europop 2010}

As noted in the text, Eurostat has recently updated its population projections for EU member countries. Table A.1 and Figure A.1 compare the basic assumptions underlying the two Europop projections. Europop 2010 is a bit more optimistic than its predecessor regarding the evolution of life expectancy of both males and females and assumes a rather different time path of net migration inflows. In view of the sharp decline in inmigration observed during recent years as a result of the current crisis, the time path of migration assumed in Europop 2010 seems more plausible than that projected in the earlier exercise. In spite of this, average yearly inflows are almost identical in the two scenarios.

Table A.1: Assumed values of key demographic parameters in 2060

\begin{tabular}{lcc}
\hline & $\begin{array}{c}\text { Europop } \\
\text { Total fertility rate }\end{array}$ & $\begin{array}{c}\text { Europop } \\
\text { Ton }\end{array}$ \\
\cline { 3 - 3 } Life expectancy at birth - males & 1.56 & 2010 \\
Life expectancy at birth - females & 84.9 & 1.56 \\
\hline
\end{tabular}

Figure A.1: Net inmigration projections, Europop 2008 vs. 2010

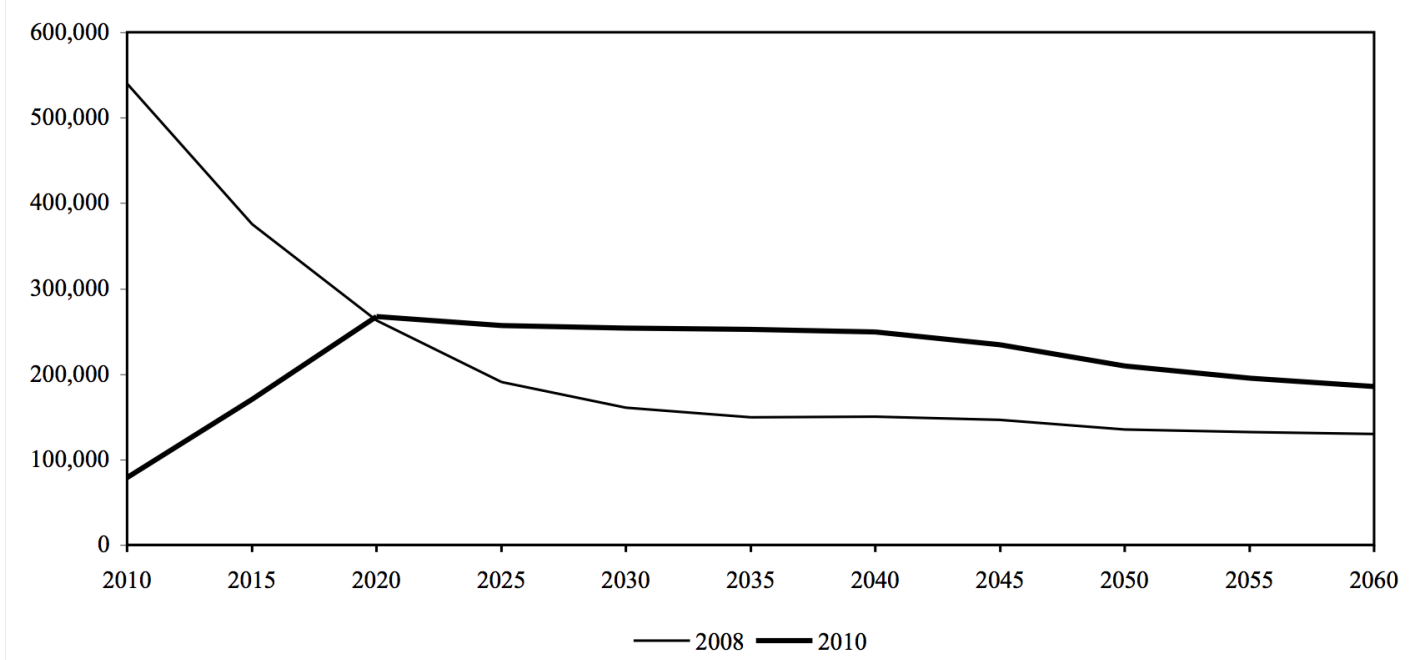

The difference in migration profiles has the expected effect on the time path of the dependency rate (defined here as the ratio betweeen the population aged 65 or more and the population between 15 and 64 years of age). Since inmigration is slower in the Europop 2010 scenario during the first half of the period and faster during the second half, the dependency ratio rises faster at first and then falls below the path expected in the previous exercise. The effect of this on the net financial balance on the pension system is straightforward. Other things equal, switching from Europop 2008 to Europop 2010 will bring the system into deficit at a somewhat earlier date but will also modestly reduce the severity of its financial problems in the final part of the sample period. It should be emphasized, however, that the results of the exercises undertaken in this paper would not change qualitatively with the adoption of the new Eurostat projections as our starting point. 
Figure A.2: Projections of the old-age dependency ratio, Europop 2008 vs. 2010

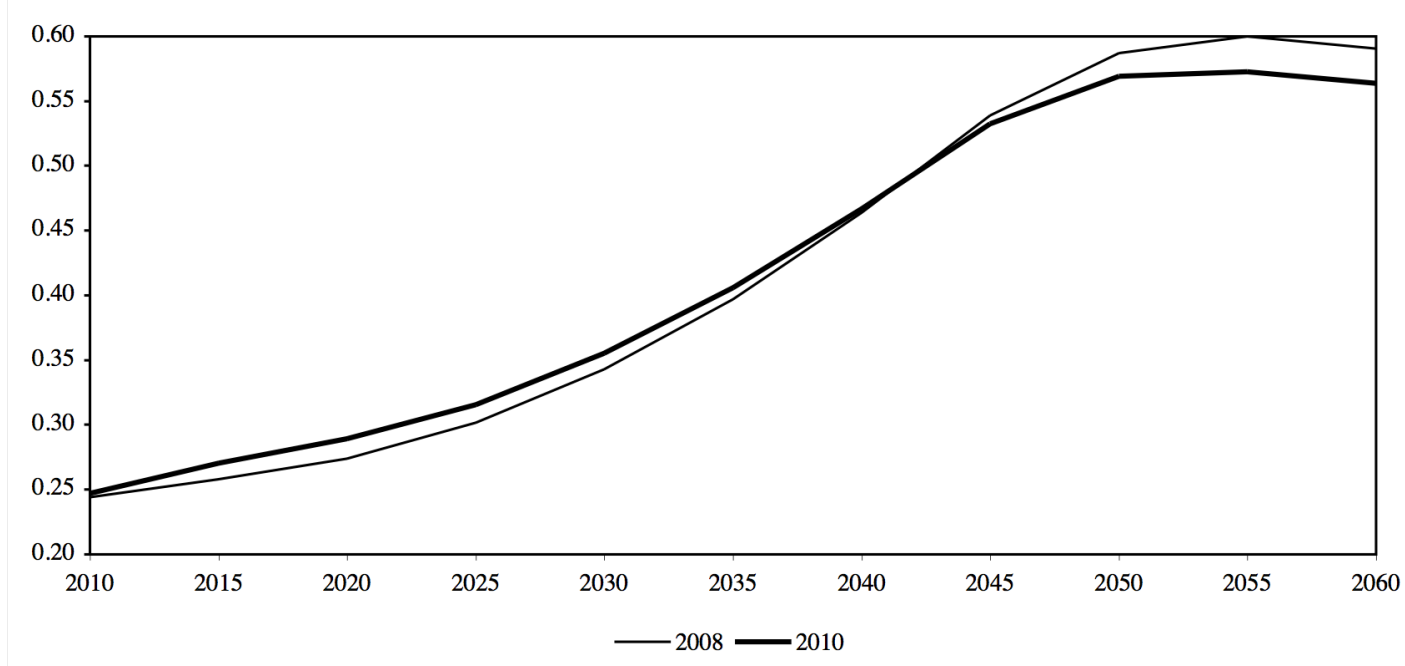




\section{References}

Alonso, J. and I. Conde (2007). "Reforma de las pensiones: la experiencia internacional." Información Comercial Española, Revista de Economía, 837, July-August, pp. 179-93.

Bank of Spain (2011). Informe Anual 2010. Banco de España, Madrid. http://www.bde.es/webbde/es/secciones/informes/Publicaciones an/Informe anual/ anoactual/

Barea, J. et al (1995). El sistema de pensiones en España: análisis y propuestas para su viabilidad. Círculo de Empresarios, Madrid.

Barea, J., M. Carpio, E. Domingo et al (1996). "Escenarios de evolución del gasto público en pensiones y desempleo en el horizonte 2020." Documento de Trabajo, Fundación BBV.

Barea, J., J.M. González-Páramo y J. Velarde (1997). Pensiones y prestaciones por desempleo, 2a ed., Fundación BBV, Bilbao.

Boldrin, M., J. J. Dolado, J. F. Jimeno y F. Peracchi (1999). "The future of pension systems in Europe." Economic Policy 29.

Boletín Oficial del Estado (BOE, 2011). Ley 27/2011, de 1 de agosto, sobre actualización, adecuación y modernización del sistema de la Seguridad Social. http:/ / www.boe.es/boe/ dias/2011/08/02/pdfs/BOE-A-2011-13242.pdf

Boletín Oficial del Estado (BOE, various years). Ley General de la Seguridad Social. Texto refundido y actualizado al 3 de enero de 2008.

http:/ / www.albertforcadell.com/wp-content/ uploads/2008/03/ley-general-de-laseguridad-social-rdl-1-1994.pdf

Conde-Ruiz, J. I. and J. Alonso (2006). “El sistema de pensiones en España ante el reto del envejecimiento." Presupuesto y Gasto Público 44, pp. 51-73.

Conde-Ruiz, J. I. and C. I. González (2011). "Reforma de Pensiones 2011: una Primera Valoración." FEDEA. Mimeo.

Cotlear, D., editor (2011). Population Aging: Is Latin America Ready? World Bank, Washington D.C.

da Rocha, J. M. and F. X. Lores (2005). “¿Es urgente reformar la Seguridad Social?” Mimeo, Universidad de Vigo.

de la Fuente, A. and R. Doménech (2010). "Aging and real convergence: challenges and proposals", in J. F. Jimeno (ed.), Spain and the Euro: The Ten First Years. Bank of Spain, Madrid, pp. 191-273).

Spanish version available on-line at: http:/ /ideas.repec.org/p/bbv/wpaper/0906.html

de la Fuente, A. (2011). “A simple model of aggregate pension expenditure." Mimeo, Instituto de Análisis Económico (CSIC), Barcelona.

http://ideas.repec.org/p/aub/autbar/871.11.html

Devesa, J. E. (2009). "La pensión de jubilación: reformulación de la tasa de sustitución para la mejora de la equidad y sostenibilidad del sistema de la Seguridad Social. Resultados basados en la MCVL." Mimeo, Universidad de Valencia. http:// www.seg-social.es/Internet 1/Estadistica/FondodeInvestigacio48073/ EstudiosFIPROS/ estudiospremiosf09/index.htm

Díaz Giménez, J. and J. Díaz Saavedra (2006). "The demografic and educational transitions and the sustainability of the Spanish public pension system." Moneda y Crédito (222), pp. 225-70. 
Díaz Giménez, J. and J. Díaz Saavedra (2008). “The Spanish public pension system: sustainability and reforms." Mimeo, IESE Business School, Madrid.

Díaz-Gimenez, J. y J. Díaz-Saavedra (2010). "Parametric Reforms of the Spanish Pension System: a Quantitative Analysis." Mimeo, IESE Business School, Madrid. http://javierdiazgimenez.com/res/pen3-a12.pdf.

Doménech, R. and A. Melguizo (2008). "Projecting pension expenditures in Spain: on uncertainty, communication and transparency." Forthcoming in Franco, D. (ed.), Fiscal Sustainability: Analytical Developments and Emerging Policy Issues. Banca d'Italia, Roma, pp. 707-30.

Economic Policy Committee (EPC, 2006). The impact of aging on public expenditure projections for the EU25 Member States on pensions, health care, long-term care, education and unemployment transfers (2004-2050). European Economy, Special Report no. 1/2006.

Eurostat (2011). Population projections, Europop 2010. http:/ / epp.eurostat.ec.europa.eu/portal/page/portal/population/data/database

Gil, J., M. A. López, J. Onrubia, C. Patxot and G. Souto (2007). "A projection model of the contributory pension expenditure of the Spanish Social Security system: 2004-2050." Hacienda Pública Española/Revista de Economía Pública 182(3), pp. 75-114.

Government of Spain and others (ASE, 2011). Acuerdo Social y Económico para el crecimiento, el empleo y la garantía de las pensiones. Mimeo, Madrid. www.la-moncloa.es/docs/Acuerdo.pdf

Herce, J. A., V. Pérez Díaz et al (1996). La reforma del sistema público de pensiones en España. Servicio de Estudios de La Caixa, Barcelona.

Instituto Nacional de Estadística (INE, 2005). Proyección de la Población de España a Largo Plazo, período 2002-2060. http://www.ine.es/metodologia/t20/t2030251h.htm.

Instituto Nacional de Estadística (INE, 2010). Proyecciones de la población de España a largo plazo, 2009-49. En Base de datos electrónica INEbase. Demografía y población. Estimaciones y proyecciones. Madrid. http://www.ine.es/inebmenu/mnu cifraspob.htm

Instituto Nacional de Estadística (INE, 2011a). Contabilidad Nacional de España. En Base de datos electrónica INEbase. Economía: Cuentas Económicas. Madrid. http://www.ine.es/inebmenu/mnu cuentas.htm

Instituto Nacional de Estadística (INE, 2011b). Cifras de población y censos demográficos. En Base de datos electrónica INEbase. Demografía y población. Madrid. http://www.ine.es/inebmenu/mnu cifraspob.htm

Instituto Nacional de Estadística (INE, 2011c). Indicadores demográficos básicos. En Base de datos electrónica INEbase. Demografía y población. Análisis y estudios demográficos. Madrid.

http://www.ine.es/inebmenu/mnu analisis.htm

International Monetary Fund (IMF, 2010). "From Stimulus to Consolidation: Revenue and Expenditure Policies in Advanced and Emerging Economies". Fiscal Affairs Department, Washington D.C.

Internacional Monetary Fund (IMF, 2011). "Spain. Selected Issues". IMF Country Report No. 11/216. Washington D. C.

Jimeno, J. F. (2000). “El sistema de pensiones contributivas en España: cuestiones básicas y perspectivas en el medio plazo." CREI, Barcelona. 
Jimeno, J. F. and O. Licandro (1999). "La tasa interna de rentabilidad y el equilibrio financiero del sistema español de pensiones de jubilación." Investigaciones Económicas XXIII(1), pp. 129-43.

Jimeno, J.F., J.A. Rojas and S. Puente (2008). "Modelling the impact of aging on social security expenditures." Economic Modelling 25, pp. 201-224.

Ministerio de Economía y Hacienda (MEH, 2011). Programa de Estabilidad España 20112014.

http:// www.meh.es.

Ministerio de Trabajo e Inmigración (MTIN, 2011a). Boletín de Estadísticas Laborales. Protección Social: Pensiones contributivas del Sistema de la Seguridad Social: Pensiones e importe medio según clase. http:// www.mtin.es/estadisticas/bel/index.htm

Ministerio de Trabajo e Inmigración (MITIN, 2011b). Proyecto de Presupuestos de la Seguridad Social, ejercicio 2011. Informe Económico Financiero y Anexo al Informe Económico- Financiero. Secretaría de Estado de la Seguridad Social, Madrid. Sitio web de la Seguridad Social: Estadísticas e Informes: Presupuestos y Estudios: Presupuestos: Presupuestos de la Seguridad Social 2011: Información complementaria: Informe económico-financiero.

http:/ / www.seg-

social.es/Internet 1/Estadistica/PresupuestosyEstudi47977/Presupuestos/Presupuestos delaSeguridadSocial2011/Informacioncomplementaria/index.htm

Ministerio de Trabajo e Inmigraciíon (2011c). Sistema de la Seguridad Social. Cierre provisional presupuesto ejercicio 2010. http:// www.tt.mtin.es/periodico/seguridadsocial/201101/SS20110119.htm

Ministerio de Trabajo e Inmigración (MITIN, 2008). Estrategia nacional de pensiones. Madrid.

Ministerio de Trabajo y Seguridad Social (MTSS, 1995). La Seguridad Social en el umbral del siglo XXI. Madrid.

Moral-Arce, I., C. Patxot and G. Souto (2008). "La sostenibilidad del sistema de pensiones. Una aproximación a partir de la MCVL." Revista de Economía Aplicada XVI(E1), pp. 29-66.

OECD (2009). Pensions at a Glance, 2009: Retirement-income systems in OECD countries. Paris.

OECD (2011). Pensions at a Glance, 2011: Retirement-income systems in OECD countries. Paris. 